\title{
EVALUATION OF MICRO, SMALL AND MEDIUM ENTERPRISES DEVELOPMENT PROGRAM IN PT FREEPORT INDONESIA
}

\author{
Theresia Oktavia \\ Freeport Indonesia \\ theresia.sadipung@gmail.com
}

\begin{abstract}
This research is aimed to evaluate the implementation of Micro, Small and medium enterprise development Program in PT Freeport Indonesia. The method used for this research was qualitative descriptive, using CIPP (Context, Input, Process, and Product) evaluation model. Primary data was obtain through interviews and observation, and secondary data document study. The results showed that Program Context, Input and process were classified as high category, while outcomes as moderate categories. The overall evaluation shows Moderate categories.The Program was rendered effective to achieve the goal of enhancing the Micro, Small and Medium enterprise Development.It should be continued and further enhanced by the management to acquire better enterprise graduates.
\end{abstract}

Keywords: Evaluation of Program, Micro, small and medium enterprise, PT Freeport Indonesia

Small and Medium Micro Enterprises (MSMEs) have an important role in Development, UMKM is a stand-alone productive business unit undertaken by a business entity or an individual in the economic sector according to Tulus Tambunan (2012: 11).

The empowerment of UMKM in Indonesia has been based on Law number 20 year 2008 on Micro, Small and Medium Enterprises. PT Freeport Indonesia is a Contractor from the Government of Indonesia, PT Freeport Indonesia is an affiliate of Freeport -Mc Moran Copper and Gold Inc. Which mines, processes and explores ores containing copper, gold and silver. With operational areas in the highlands of Mimika district, the province of Papua, Indonesia, referring to Law 40 of 2007 article 74 concerning a limited liability company expresses clearly the attachment of social and environmental responsibility to any company that conducts its business activities in the field or related to Resources. One of the programs undertaken by PT Freeport Indonesia is Corporate Social Responsibility Program which is community development which is one of the programs launched by PTFI as the contribution of the company to the economic development of Papua, in line with the Vision of PT Freeport Indonesia is at the closing of the mine where PT Freeport Indonesia has fulfilled all of its social commitments to promote the quality of life and livelihoods of affected communities, particularly the indigenous peoples of Amugme and Kamoro, the five tribes of kinship (Mee / Ekari, Dani, Damal, Nduga, Moni) and other Papuan communities.

Social Outreach \& Local Development (SLD) is one of the departments in PT Freeport Indonesia that plays an important role in fulfilling PT Freeport Indonesia's commitment, one of the Programs managed by PT Freeport Indonesia Social Outreach \& Local Development (SLD)) is the UMKM Development Program. The Micro, Small and Medium Enterprises (PP- UMKM) development program aims to develop the economic activities of local communities by providing guidance and assistance to potential Papuan entrepreneurs.

Community empowerment efforts that have been undertaken by the Company based on data in the Annual Report of 2013 Community affairs Economic Program for small and medium enterprises (MSMEs) has absorbed "1,031 laborers in which 125 are women, five (5) Women managed and Of all Papuan entrepreneurs $78 \%$ come from 7 Tribes ", Program - UMKM guidance 
implemented by PT Freeport Indonesia directly absorb labor and contribute to society in Government and Society itself.

Community development in line with Limited Liability Company Law (PT) No.40 / 2007, article 74, it is clear that (1) the company which runs its business activities in the field and / related to natural resources must carry out the social and environmental responsibilities, It is concluded that the Company has strived to implement its obligations in accordance with Law No. 40 of 2007 through its CSR Program Program and one of the Programs is the development of MSMEs long before the Law No. 40 of 2007 was initiated in which the program started since 1991, However, there are still problems that the Community Participants of the Development Program are experiencing difficulties to be independent and there are also community demands that fall into the category of active demands received by PT Freeport Indonesia in 2015 and in previous years ie claims related to compensation of communal rights,Environment, and compensation of remuneration in this case the Contract business request.

According to Fitzpatrick, Sanders and Worthen (2004: 5), that evaluation is a decision on the price or value of a program and helps to make decisions about the program. A more holistic understanding, put forward by Stufflebeam and Shinkfield (2007: 329), ie evaluation as a process Systematic, providing information that can be used as a consideration for determining the value, the benefits of the intended goals and their impacts, to help make decisions. Based on the above description, the evaluation of the training program is the process of providing systematic information about a training program, assessing and determining its benefits, Making decisions about the training program, Program evaluation, according to Royse, Thyer, and Padgett (2009: 3), is a systematic process of gathering and analyzing information, in order to make informed decisions.

This study aims to conduct an evaluation to gain an in-depth understanding of the Program Concept, Program Inputs, Program Implementation, and Results of Small and Medium Micro Enterprise Development Program at PT Freeport Indonesia.

\section{METHODS}

The research was conducted using evaluative approach using CIPP evaluation model according to Stufflebeam, which consist of Context, Input, Process, and Product. The method used is qualitative descriptive. The unit of analysis of this research is the implementation of the Small and Medium Micro Enterprise Development program in PT Freeport Indonesia. The research subjects are the purposive sampling of the Program Operator Department, the Beneficiary Employer, and the Users of UMKM Entrepreneurs Business Services and the Officer Corporate Communiation of PT Freeport Indonesia. The data collected were primary and secondary data, using interview technique, observation and document study. Data validation is carried out with triangulation of data sources and techniques. Datakualitatif analysis is done through reduction activities, data presentation, and data verification (Miles and Huberman, 1994: 8-12). Data collected compared to evaluation criteria are assessed and interpreted using assessment and interpretation guidelines Which consists of three categories: (a) the value of 1 low rating Evaluation Criteria is not fulfilled completely or partially fulfilled, under fifty percent $(\leq 50 \%)$ of the number of criterion items (b). Niai 2 moderate ratings Evaluation criteria are partially met, $50 \%$ or more of the number of item criteria (c). Value 3 High Rank Criteria Evaluation is fulfilled all $100 \%$. Based on the results / research findings carried out discussion then further drawn conclusions and recommendations for the continuation of the program.

\section{RESULTS AND DISCUSSION}

The results of the evaluation of the Small and Medium Micro Enterprise Development Program at PT Freeport Indonesia are as follows:

\section{Context Evaluation}

a. Objectives and Program Objectives:Clearly written, sustainable goals and objectives The Program is prepared for the benefit of Community development, based on consideration of the 
needs of both the Company, the Government and the Company with the target beneficiaries being the Papua Community located around the operational area of PT Freeport Indonesia. Vision and Mission Programs tailored to the needs of Jasavisi recipients contain values that ensure sustainability and long-term success and mission are activities to realize the vision of the program. Vision and mission of Small and Medium Micro Enterprise Development Program meets the characteristics of: imagible, Desirable, feasible, focused, flexible, and communicable. This is in accordance with the characteristics proposed by Nawawi, (2005: 122).

b. Basic Programming Preparation Policy: The main reference in the development of this MSME Development Program is based on the Company's commitment to adhere to the ten ongoing ICCM (Council on mining and metals) Practices and is supported by law governing the government's vision and mission of the Development Program Micro Small and Medium Enterprises The preparation of this program is based on the legal aspect and relevance to the management that has been passed the Law Article 74 no. 40 of 2007, Law No. 25 of 2007 on capital investment of articles 15,17 and 34 on CSR as the Corporate Social and Environmental Responsibility which requires limited liability company (PT) engaged in natural resources to carry out its social and environmental responsibilities Specifically around the operations of the PT is operating and throughout the territory of Indonesia Overall, the results of the program context evaluation get the category High scaling scale 3 Evaluation Criteria met all 100\%.

\section{Program Input Evaluation (Input Evaluation)}

a. Organizational structure and implementation of the Development MSME Program (Micro, Small and Medium Enterprises): With a clear organizational structure is a strategy to achieve goals, a strategy is a set of action plans to achieve goals (Anthony, Kacmar, and Perrewe, 2010: 9). Organizational Structure in the Implementation of Micro Small and Medium Enterprise Development Program as a clear tool in improving work effectiveness in the presence of Tiered Supervision; And enhance cooperation in related departments. Implementation of this Development Program describes a procedure or unity of concepts with components that have interrelationship with each other. Implementation This development program uses system design, with stages: needs analysis, program planning, program setting, program preparation, program implementation (including supervision and control and evaluation), and termination. Implementation The development is in accordance with the training pro- cess according to Dessler (2008: 295), and Anthony, Kacmar, and Perrewe (2010: 276). MSME Development Program at PT Freeport Indonesia is managed by the Division of Community affairbagian Social Local Development Department (As Executor of UMKM Development Program The Program is managed by SLD Dept. and the Division is headed directly by the Executive Vice President responsible for all Community Development Programs and reports to the President Director, there is a Maximum Program Support Facility which is the Company provides training venue, Guidance and Loan Revolving Loan Facility, Qualified Coach according to need, Evaluation Criteria fulfilled Rating scale 3.

b. Program Implementation Procedure: The results showThere are Program Plans with Program Implementation Procedures such as Having operational standards Procedures arranged by the Social Local Development Department for the development of Small and Medium Micro Enterprises based on the value of International Council on Mining and Metals, Good planning will determine the smoothness of the program implementation, therefore quality control and supervision Important program and needs to be well planned Sukukinata, Jami'at, and Ahman (2010: 37), Evaluation Criteria fulfilled 100\% Assessment Scale 3.

c. Program Financing:Specific budget allocation for Small and Medium Micro Enterprise Development Program, PT Freeport Indonesia as the sole donor, establishes Yayasan Bina Usaha Mandiri to overcome obstacles from the Busi- ness Officers from the budget side through the provision of revolving funds loan in an easy way, Fast and cheap, because one of 
the most important aspects of business development is Capital, it shows that there is a clear funding source for this Program, Evaluation Criteria fulfilled Assessment Scale 3.

d. Government Support:Having Regulation from Governmental Party through Minister of Finance Decree Number 135 / PMK.05 / 2008 concerning Credit Guarantee Facility for People's Business facility which contains Presidential Instruction No. 6/2007 concerning real sector acceleration policy and empowerment of Micro Small and Medium Enterprises (MSME), based on the consideration of Law No. 7 of 1992, Law No. 9 of 1995 on Small Businesses, and in the Development of Small and Medium Micro Enterprises This Government Provides Support such as Government Award in 2010 Leon Leon Kus and Verdy Abdullah From the Coordinating Ministry for People's Welfare. Thus there is support from the government in terms of the policy of the Act and the Awards to the Program Implementer, then the criteria are met the scoring scale of 3 (high).Overall, the results of input evaluation (input) got the category met all the Assessment scale 3 (high).

\section{Evaluation Implementation Program (Process Evaluation)}

a. Conformity between purpose and Implementation

1) Program Implementation is carried out in accordance with the objective of the Development Program to Develop economic activities for indigenous Papuans that educate the entrepreneurs' communities to be independent and able to compete in more competitive markets, in the Implementation of Development Program carried out by Guidance even to the Supervision of this Program Through Evaluation of the results of the implementation of the Package by Entrepreneurs, it is found that there is supervision in accordance with the opinion of Sukmadinata, Jami'at, and Ahman (2010: 45), who said that good supervision, monitoring and evaluation activities must meet the main requirements, (Planning) is clear, complete and integrated.

2) Understanding of Beneficiary Programs:The results of the study found that the program has been well understood by the Participants of the Development Program Program so that the Program Socialization is successful, because the success of a Program is very dependent on the understanding of the beneficiaries and the beneficiaries of the Program because in the case of Development then both parties must Prepare especially the participants of the development program in accordance with Mathis and Jackson (2008: 270), which said that the effectiveness of learning activities of the training participants, determined by the readiness of the training participants themselves in the learning process (learning readiness).

3) Use of Budget:The use of the budget is done according to needs and realized in accordance with the plan, the analysis is done first for each budget request this makes the effectiveness of budget usage increases.

4) Monitoring and Transparency Program Implementation:PT Freeport Indonesia operates a transparent and accountable reporting system implemented by adopting a standard reporting system in accordance with the Global Reporting Initiative (GRI) and elements developed by the International Council Mining and Metals. Supervision is urgently needed for sustainability A Program, in the Small and Medium Micro Enterprise Development Program in PT Freeport Indonesia has been conducted Good supervision of the mechanism of oversight carried out both Internally Organization and there is an independent audit agency, Reporting related to the Development Program activities carried out regularly and transparently so that can be seen by shareholders, Stakeholders and Government which are packaged in the form of Community Development Program Report in holistic way. Overall, the results of the evaluation of the implementation of the program are assessed by the assessment criteria of 3 criteria met. 


\section{Evaluation of Program Results (Products Evaluation)}

a. A. Results of Implementation of UMKM (Small and Medium Micro Enterprise) Development Program at PT Freeport Indonesia for PT Freeport Indonesia:Program Implementation Results for Companies shows the current Market Segment that 88 Employers provide services to PT Freeport Indonesia in the form of Supplier and Service Contact) or $62 \%$ increase is calculated from the data of the last five years since 2011. The achievement of these results is in line with the objectives of the Small Enterprise Development Program as a management consulting agency that establishes innovative, dynamic and independent Papuan entrepreneurs conducting Learning Processes to develop the community As a learning process to provide specific knowledge needed by employees to carry out their duties and work (Dessler, 2008: 294).

The achievement is in accordance with the target of the Program: The entrepreneurial entrepreneurial society understands the opportunities and risks in entrepreneurship, Of the Small and Medium Micro Enterprise Development Program in line with Article 74 of Law No.40 of 2007, describes CSR as the social and environmental responsibility of the company, requires a Limited Liability Company (PT) engaged in natural resources to carry out social responsibility and The environment especially around the operations of the PT as well as throughout the territory of Indonesia, PT Freeport Indonesia undertakes efforts to minimize negative impacts and maximize positive impacts for all stakeholders in the Government, the Society and the Company itself is in line with the definition of CSR Indonesia as a real effort From business entities to minimize negative impacts and maximize the positive impacts of its operations on all stakeholders in the economic, social and environmental realms to achieve sustainable development goals (Mahmudin Yasin 2013; 5)

In maintaining the business and creating a conducive business, PT Freeport Indonesia carries out an awareness of the environment in which the Company operates. This is in line with the expert's opinion that for corporate social responsibility (CSR) as a concern for business organizations to act in their own way in Serving the interests of the organization and external public interests Schermerhorn in Edi Suharto $(2007 ; 102)$.

In relation to one of the problems of the Program Evaluation that there is still a Request for Retaliation of Services or Contract of Work of the Papuan Community to the Program, Program Development of the Business Incubator Program since 1991 and by 2015 there is an equal active demand from the Papuan Community for the demand for remuneration. Analyzes based on the data obtained that there is no decrease in Demand Contract Work even though there are already successful Papuan community after following this Development Program. Requests or demands from local Communities in relation to Contract Requests herded back in 1991 in accordance with the policy base taken during the preparation of the Program in which All the workforce in the local community wishes to become employees of PT Freeport Indonesia. Repeated requests are influenced by social and cultural factors where most people still have an understanding of how Papuan life is the responsibility of PT Freeport Indonesia, where this society already has a social unity and its self-defined boundaries are in harmony with Burhan's theory Bungin (2006: 29). Says society is a group of people who have lived and worked together long enough for them to organize themselves and regard themselves as a social unity with clearly defined boundaries. This statement states that people are people who live together, which produces culture.Criteria for success evaluation a) Increasing number of MSME entrepreneurs (as per criteria) High Ranking (3), b) Demand for Work Contracts Decreased compensation (As Criteria) Moderate Ratings (2).

b. B. Results of the Implementation of Micro, Small and Medium Enterprises Development Program at PT Freeport Indonesia for Beneficiary Communities:The results of the Program's implementation for the community have shown success with the Achievement of the Number of Entrepreneurs who have Graduated and got Jobs in PT Freeport Indonesia 49 Employers including 20 of them get the Project from Outside of the Company, Increasing the quality of 
human resources from the community that are food gathering become entrepreneurs, Increasing the amount of income of the Community Entrepreneur Micro Small and Medium Enterprises as much as $124 \%$ for the comparison of data last 5 years since the yearResults achieved in accordance with the purposeEducation and Development to learn the skills- New skills that will improve their work performance (Handoko, 2011: 107). We know the level of independence of Entrepreneurs is still not maximized this is proclaimed with the existing entrepreneurs who have graduated and returned to the coach to get Consultation assistance, the purpose of the Guidance so that Participants can be independent and solve all the problems themselves because it has been equipped with knowledge, skills and attitude development, to increase knowledge, skills, develop attitude to face change, generate motivation, support, feedback and combine the application of theory and Psychomotor practices (Reksohadiprojo and Handoko, 2001: 349).

This Development Program has yielded positive results Increasing trust between ethnic communities by conducting joint activities in training, becoming one of the factors to minimize tribal dispute because it has reduced conflict, give each other job that employer give Work to brother, it can be concluded happened Capital Development Social development because of the development of resources that have an impact on Economic Development menigkatnya living standards of Entrepreneurs and reduce unemployment this is in accordance with Opinion that dikemukanan by Social capital itself according to Cohen and Prusak is a collection of active relationships between people; Trust, mutual understanding and similarity of values and behaviors that bind members in a network and community that allows for cooperation (Jhon Fied 2008; 70).

Evaluation criteria of success a). Program considered to be beneficial to the Community (as per criteria) rating $3 \mathrm{~b}$ ) Increase Income of Entrepreneur Assistance (as per criteria) rating 3 and c) the presence of Micro Small and Medium Enterprises participants who get Jobs outside PT Freeport Indonesia but still Have communication in the form of consultation to the coach of SLD (as per criterion) rating 2.

c. Results of Program Implementation For The Government:Community Development Program focuses on improving people's living standards by looking at indicators of increasing revenue, Underlying Undip - CSR law is a legal foundation to unite communities for the benefit of Community Development. Community Development is a Process whereby there is a group effort for themselves and united with government authorities to improve the economic, social and cultural conditions of society, to integrate society into the life of the nation, and enable them to contribute fully to national progress and Community Development is an activity Community development involving local empowerment through collective community groups to control decisions, projects, programs and policies affecting them as a community (Sanders \& Lohman 2014: 6-7), Achievements through Small and Medium Enterprises Development Program shows the impact that Positive for the Government is Based on the Annual Report Communities Affair PT Freeport Indonesia 2016, known absorption of labor in Comparison of 5 years increased labor absorption increased 55\% from 2011 to 2016, thereby decreasing the unemployment rate in the Papuan community by 1,625 souls.

The people's economy is increasing along with the increasing Income of the People of Papua through Small and Medium Micro Enterprise Program, the growing of trust between the people due to the development of resources so that there can be economic improvement as evidenced by the increase in the income of the Buered Entrepreneurs and the increasing of labor absorption rate for Mimika. Increased Revenue is a positive effect for the community from Small and Medium Enterprises Development Program so it positively impacts the Government with the growth of social capital values in society, as the Company as private party able to increase Social Capital, World Bank defines social Capital as - norms and relations Socially embedded in social structures that enable people to coordinate actions to 
achieve desired goals. Successful evaluation criteria a). There is an increase in the number of manpower absorbed through this program (as per criteria) Rank 3, b) Increasing community economy (According to Criteria) Rank 3 c) and found an increase in trust between societies developing social capital.

5. Attitudes and Performance of Entrepreneurs Passed UMKM Development Program shows independence.

Achievement Change attitude to entrepreneurship, Visible Improved Skill but some who pass still return to the coach for consultation if there is conflict Pembina help in the settlement, confidence in solving the problem is still wrong One factor in the impediment of independence is in the opinion of Tantaway (2005: 87), who argues that self-esteem is one aspect of personality that will give a strong belief in himself to do or act. Unconfident people have negative selfconcept, lack of trust in their ability, and often close themselves. Ability to cooperate adequately can be a factor inhibiting independence and success of the program because a) Low educational factors lead to less confidence. b) a very strong social-cultural factor with strong emotions and very spontaneous action because it is a dominant pattern that develops genetically or hereditary, c) A perspective which sees that the Company is obliged to ensure the lives of the Papuans that lead to work ethic Which is less ambitious, this fact is in accordance with Community Theory: society is groups of people who occupy a certain territory, which live relatively longer, communicate with each other, have symbols of certain rules and legal systems that control the actions of members Society, has a stratification system, is aware of it as a member of that community and is relatively self-sustaining (Burhan Bungin 2006; 159).

Evaluation criteria of success a) there is a change of attitude to entrepreneurship from entry and after completion of development (according to Criteria) rank 2, b) there is an increase of knowledge and business management skills by not returning consultation to the coach, solving problems independently, Freeport Indonesia (as per criteria) of rank 2, c) Ability to cooperate with other communities having similar interests both within the Department within PT Freeport as well as outside parties (Criteria) Rank 2Overall Product Evaluation gets a 2 (Moderate) Criteria Evaluation criteria is partially met, $50 \%$ or more of the number of criteria.

\section{CONCLUSION}

Based on the results and discussion, it can be concluded as follows: (1) Context Evaluation: The objectives and objectives of the Program meet the High criteria (3), Program Policies meet the High Criteria (3); (2) program input (input evaluation): Criteria (3) program implementation: implementation of learning program and activity activity Criteria (3) and 4. Program results: program outcomes, for the Company, Society and Government moderate criteria (2)Overall, the Evaluation of Micro Small and Medium Enterprise Development Programs, which were rated on average: 2.73 Moderate Assessments with Evaluated Criteria, 50\% or more of the Criteria.Thus, the program is effective for the Micro, Small and Medium Enterprises (PP- UMKM) development program aimed at developing local economic activities by providing guidance and assistance to potential Papuan entrepreneurs for the economic development of Papuan communities.

\section{REFERENCES}

Anthony William P., Kacmar K. Michele, dan Perrewe Pamela L. (2010).Human Resource Management: A Strategic Approach. United States: Cengage Learning.

Burhan Bungin. (2006).Sosiologi Komunikasi. Teori, Paradigma, dan diskursus Teknologi Komunikasi di Masyarakat. Kencana: Prenada Media Group.

Coleman. (2012). "Social Capital Development in Youth Development Programming: A Case Study of California 4-H, Youth, Families and Communities Youth Development Program.

Dessler Gary. (2008).Human Resource Management, $11^{\text {th }}$ Edition. New Jersey: Pearson PrenticeHall.

Erif Faturhrahman, Tubagus. Doc. Kebijakan Corporate Social Responsibility PT Freeport Indonesia dalam Pemenuhan hak ekonomi sosial budaya masyarakat Lokal Papua. 
Fied, John. (2008). "Social Capital".Routledge TaylorFrancis Group London and New York.

Fitzpatrick, Jody L., Sanders, James R. dan Worthen, Blaine R. (2004).Program Evaluation: Alternative Approaches and Practical Guidelines $3^{\text {rd }}$ edition. Boston: Pearson Education.

Mahmuddin Yasin, Agus Suherman, Muhammad Hatta. (2013).Perusahaan Bertanggung Jawab.

Nawawi Hadari. (2006). Manajemen Strategik Organisasi Non Profit Bidang Pemerintahan: Dengan Ilustrasi di Bidang Pendidikan. Yogyakarta: Gadjah Mada University Press.

Owen, John M. (2006). Program Evaluation: Forms and Approaches $3^{\text {rd }}$ Ed. Australia: Allen \& Unwin.

Reksohadiprojo, Sukanto dan Handoko, Hani T. (2001). Organisasi Perusahaan: Teori Struktur dan Perilaku. Yogyakarta: BPFE-Yogyakarta.

Royse David, Thyer Bruce A., Padgett Deborah K. (2009). Program Evaluation: An Introduction, $5^{\text {th }}$ Edition. New York: Cengange Learning. 